University of Nebraska - Lincoln

DigitalCommons@University of Nebraska - Lincoln

Faculty Publications: Department of

Entomology

Entomology, Department of

$12-1-2004$

\title{
Buffalograss Germplasm Resistance to Blissus Occiduus (Hemiptera: Lygaeidae)
}

\author{
Osman Gulsen \\ University of Nebraska-Lincoln \\ Tiffany Heng-Moss \\ University of Nebraska-Lincoln, thengmoss2@unl.edu \\ Robert C. Shearman \\ University of Nebraska-Lincoln, rshearman1@unl.edu \\ P. Stephen Baenziger \\ University of Nebraska-Lincoln, pbaenziger1@unl.edu \\ Donald J. Lee \\ University of Nebraska-Lincoln, dlee1@unl.edu
}

See next page for additional authors

Follow this and additional works at: https://digitalcommons.unl.edu/entomologyfacpub

Part of the Entomology Commons

Gulsen, Osman; Heng-Moss, Tiffany; Shearman, Robert C.; Baenziger, P. Stephen; Lee, Donald J.; and Baxendale, Frederick P., "Buffalograss Germplasm Resistance to Blissus Occiduus (Hemiptera: Lygaeidae)" (2004). Faculty Publications: Department of Entomology. 117.

https://digitalcommons.unl.edu/entomologyfacpub/117

This Article is brought to you for free and open access by the Entomology, Department of at DigitalCommons@University of Nebraska - Lincoln. It has been accepted for inclusion in Faculty Publications: Department of Entomology by an authorized administrator of DigitalCommons@University of Nebraska - Lincoln. 


\section{Authors}

Osman Gulsen, Tiffany Heng-Moss, Robert C. Shearman, P. Stephen Baenziger, Donald J. Lee, and Frederick P. Baxendale 


\title{
Buffalograss Germplasm Resistance to Blissus Occiduus (Hemiptera: Lygaeidae)
}

\author{
OSMAN GULSEN, TIFFANY HENG-MOSS,${ }^{1}$ ROBERT SHEARMAN, P. STEPHAN BAENZIGER, \\ DON LEE, AND FREDICK P. BAXENDALE ${ }^{1}$
}

Department of Agronomy and Horticulture, University of Nebraska, Lincoln, NE 68583

J. Econ. Entomol. 97(6): 2101-2105 (2004)

\begin{abstract}
Plant germplasm collections may offer genetic variability useful in identifying insect resistance. The goal of this project was to evaluate buffalograss genotypes [Buchloë dactyloides (Nutt.) Engelm.] for resistance to the chinch bug, Blissus occiduus Barber (Hemiptera: Lygaeidae), and to relate resistance to ploidy level, chinch bug number, and pubescence. Forty-eight buffalograss genotypes from diverse geographic locations were evaluated in replicated studies under greenhouse conditions. Of the genotypes studied, four were highly resistant, 22 were moderately resistant, 19 were moderately susceptible, and three were highly susceptible to chinch bug damage. The mean number of chinch bugs was significantly different among the 48 genotypes. There was no significant correlation between chinch bug resistance and ploidy level or chinch bug resistance and pubescence. These results indicate the genetic source of resistance to chinch bugs exists in buffalograss germplasm. Highly resistant genotypes can be used in breeding programs to further improve buffalograss cultivars.
\end{abstract}

KEY WORDS Buchloe dactyloides, chinch bug, Blissus occiduus, plant resistance, turfgrass

Chinch bugs (Hemiptera: Lygaeidae) are serious pests of cool- and warm-season turfgrasses. The hairy chinch bug, Blissus leucopterus hirtus Montandon, in northern states, and the southern chinch bug, Blissus insularis Barber, in southern states (Reinert et al. 1995) cause serious damage to turfgrasses, including Bermuda grass, Cynodon dactylon (L.) Persoon; creeping bentgrass, Agrostis stolonifera L.; Kentucky bluegrass, Poa pratensis L.; perennial ryegrass, Lolium perenne L.; St. Augustinegrass, Stenotaphrum secundatum (Walter) Kuntze; zoysiagrass, Zoysia japonica Steudel; and the tall and fine fescues, Festuca spp. (Tashiro 1987). Recently, a different species, Blissus occiduus Barber, has emerged as an important insect pest of buffalograss, Buchloë dactyloides (Nutt.) Engelm., in Nebraska (Baxendale et al. 1999). The reported host range of $B$. occiduus includes barley, Hordeum spp.; corn, Zea mays L.; oats, Avena sativa L.; sorghum, Sorghum bicolor (L.) Moench; wheat, Triticum aestivum L.; bromegrass, Bromus spp.; several cool- and warm-season turfgrasses; and various native grasses (Ferris 1920, Parker 1920, Bird and Mitchener 1950, Farstad et al. 1951, Eickhoff et al. 2004). Currently, B. occiduus occurs in Arizona, California, Colorado, Kansas, Montana, Nebraska, New Mexico, and Oklahoma in the United States, and Alberta, British Columbia, Manitoba, and Saskatchewan in Canada (Bird and Mitchener 1950, Slater 1964, Baxendale et al. 1999).

\footnotetext{
${ }^{1}$ Department of Entomology, University of Nebraska, Lincoln, NE 68583.
}

Buffalograss is a perennial, warm-season, sod-forming grass that is native to the shortgrass prairies of North America (Wenger 1943). It is recommended for use on lawns, parks, cemeteries, airfields, athletic fields, roadsides, golf courses, and pastures (Beard 1973) due to its drought tolerance and low maintenance requirements (Riordan 1991). Buffalograsses have evolved a ploidy level series, including diploid, tetraploid, pentaploid, and hexaploid plants (Johnson et al. 2001). Diploids have been reported to occur only in central Mexico and southeastern Texas, tetraploids in southern proportions of the Great Plains, and hexaploids throughout the Great Plains.

Germplasm evaluation may identify genetic diversity needed to improve turfgrass performance. Johnson-Cicalese et al. (1998) found dramatic differences among buffalograss selections for mealybug (Homoptera: Pseudococcidae) resistance. Heng-Moss et al. (2002, 2003) reported considerable variation and identified tolerance to chinch bugs among 11 buffalograss cultivars evaluated. Additional resistant germplasm is needed to breed buffalograss with chinch bug resistance. To develop new cultivars, germplasm genetic structure and characterization data of germplasm are essential. The goal of this project was to detect chinch bug resistance variation among selected buffalograss genotypes and to relate resistance to ploidy level, chinch bug number, and pubescence. 
Table 1. Susceptibility of buffalograss genotypes to B. occiduus under greenhouse conditions, and their ploidy level, mean chinch bug numbers, and pubescence

\begin{tabular}{|c|c|c|c|c|c|}
\hline Genotypes & Ploidy $^{a}$ & $\begin{array}{c}\text { Level of } \\
\text { resistance }\end{array}$ & $\begin{array}{l}\text { Chinch bug damage } \\
\text { rating }^{c} \pm \mathrm{SE}\end{array}$ & $\begin{array}{l}\text { Mean no. of chinch } \\
\text { bugs/plant }{ }^{d} \pm \mathrm{SE}\end{array}$ & $\begin{array}{c}\text { Pubescence density } \\
\text { rating }^{e}\end{array}$ \\
\hline 184 & 6 & $\mathrm{HR}$ & $1.5 \pm 0.4$ & $53 \pm 16$ & $4.3 \pm 0.5$ \\
\hline $91-118$ & 4 & $\mathrm{HR}$ & $1.6 \pm 0.3$ & $92 \pm 24$ & $2.7 \pm 0.5$ \\
\hline 196 & 6 & HR & $1.6 \pm 0.3$ & $87 \pm 23$ & $1.2 \pm 0.6$ \\
\hline PX3-5-1 & $3^{f}$ & HR & $1.7 \pm 0.4$ & $74 \pm 12$ & $1.0 \pm 0.3$ \\
\hline 240 & 6 & MR & $2.2 \pm 0.8$ & $69 \pm 20$ & $3.6 \pm 0.7$ \\
\hline 193 & 6 & MR & $2.3 \pm 0.5$ & $54 \pm 15$ & $1.4 \pm 0.5$ \\
\hline 'Cody' & 6 & MR & $2.3 \pm 0.5$ & $77 \pm 14$ & $4.0 \pm 0.6$ \\
\hline 209 & 6 & MR & $2.4 \pm 0.3$ & $34 \pm 13$ & $3.3 \pm 0.5$ \\
\hline 170 & 6 & MR & $2.5 \pm 0.5$ & $92 \pm 21$ & $2.9 \pm 0.6$ \\
\hline 83 & 6 & MR & $2.6 \pm 0.4$ & $74 \pm 17$ & $3.6 \pm 0.5$ \\
\hline 203 & 6 & MR & $2.6 \pm 0.5$ & $99 \pm 24$ & $1.1 \pm 0.4$ \\
\hline 47 & 6 & MR & $2.7 \pm 0.3$ & $85 \pm 23$ & $3.2 \pm 0.8$ \\
\hline 46 & 4 & MR & $2.7 \pm 0.8$ & $80 \pm 23$ & $3.7 \pm 0.5$ \\
\hline 34 & 6 & MR & $2.8 \pm 0.8$ & $100 \pm 26$ & $3.6 \pm 0.6$ \\
\hline 136 & 6 & MR & $2.8 \pm 0.6$ & $102 \pm 21$ & $1.0 \pm 0.0$ \\
\hline 68 & 5 & MR & $2.8 \pm 0.4$ & $76 \pm 20$ & $1.0 \pm 0.3$ \\
\hline 98 & 4 & MR & $2.8 \pm 0.7$ & $78 \pm 19$ & $1.6 \pm 0.5$ \\
\hline 143 & 6 & MR & $2.9 \pm 0.8$ & $46 \pm 13$ & $1.9 \pm 0.3$ \\
\hline 89 & 6 & MR & $2.9 \pm 0.5$ & $70 \pm 25$ & $3.4 \pm 0.5$ \\
\hline $189 \mathrm{~A}$ & 6 & MR & $2.9 \pm 0.8$ & $51 \pm 15$ & $1.3 \pm 0.5$ \\
\hline 2 & 6 & MR & $3.0 \pm 0.2$ & $50 \pm 15$ & $3.6 \pm 0.8$ \\
\hline 178 & 6 & MR & $3.0 \pm 0.8$ & $83 \pm 25$ & $3.9 \pm 0.5$ \\
\hline 234 & 6 & MR & $3.0 \pm 0.6$ & $84 \pm 23$ & $2.7 \pm 0.5$ \\
\hline 'Density' & 2 & MR & $3.0 \pm 0.4$ & $53 \pm 16$ & $1.0 \pm 0.5$ \\
\hline 174 & 4 & MR & $3.0 \pm 0.8$ & $70 \pm 18$ & $1.0 \pm 0.0$ \\
\hline 'Bowie' & 6 & MR & $3.0 \pm 0.9$ & $52 \pm 18$ & $4.0 \pm 0.5$ \\
\hline 123 & 6 & MS & $3.2 \pm 0.7$ & $150 \pm 36$ & $3.5 \pm 0.7$ \\
\hline 7 & 6 & MS & $3.2 \pm 0.6$ & $84 \pm 21$ & $3.1 \pm 0.4$ \\
\hline $20 \mathrm{~B}$ & 5 & MS & $3.2 \pm 0.7$ & $60 \pm 16$ & $4.1 \pm 0.8$ \\
\hline 77 & 6 & MS & $3.3 \pm 0.8$ & $63 \pm 19$ & $3.8 \pm 0.7$ \\
\hline $45 \mathrm{~B}$ & 4 & MS & $3.3 \pm 0.8$ & $69 \pm 20$ & $3.7 \pm 0.5$ \\
\hline $78 \mathrm{C}$ & 6 & MS & $3.4 \pm 0.7$ & $60 \pm 16$ & $2.4 \pm 0.5$ \\
\hline 49 & 5 & MS & $3.4 \pm 0.6$ & $55 \pm 13$ & $3.0 \pm 0.9$ \\
\hline 132 & 4 & MS & $3.4 \pm 0.8$ & $36 \pm 12$ & $1.9 \pm 0.8$ \\
\hline 137 & 6 & MS & $3.5 \pm 0.7$ & $58 \pm 16$ & $3.0 \pm 0.6$ \\
\hline 153B & 6 & MS & $3.5 \pm 0.7$ & $74 \pm 21$ & $3.9 \pm 0.6$ \\
\hline 187 & 6 & MS & $3.6 \pm 0.4$ & $65 \pm 14$ & $1.0 \pm 0.3$ \\
\hline 66 & 5 & MS & $3.6 \pm 0.8$ & $48 \pm 13$ & $4.4 \pm 0.8$ \\
\hline 84 & 6 & MS & $3.6 \pm 0.4$ & $45 \pm 11$ & $3.5 \pm 0.6$ \\
\hline 97 & 6 & MS & $3.8 \pm 0.6$ & $50 \pm 16$ & $3.0 \pm 0.3$ \\
\hline $95-55$ & 6 & MS & $3.8 \pm 0.5$ & $91 \pm 32$ & $4.1 \pm 0.4$ \\
\hline $87 \mathrm{~A}$ & 5 & MS & $3.8 \pm 0.9$ & $57 \pm 16$ & $3.4 \pm 0.7$ \\
\hline 28 & 6 & MS & $3.8 \pm 0.7$ & $66 \pm 15$ & $1.0 \pm 0.3$ \\
\hline '378’ & 5 & MS & $3.9 \pm 0.6$ & $51 \pm 19$ & $3.5 \pm 0.5$ \\
\hline $223 \mathrm{~A}$ & 6 & MS & $3.9 \pm 0.6$ & $52 \pm 18$ & $1.2 \pm 0.4$ \\
\hline $4 \mathrm{~A}$ & 6 & HS & $4.2 \pm 0.8$ & $36 \pm 10$ & $2.9 \pm 0.8$ \\
\hline 188 & 6 & HS & $4.4 \pm 0.6$ & $38 \pm 12$ & $2.9 \pm 0.8$ \\
\hline 119 & 4 & HS & $4.5 \pm 0.8$ & $38 \pm 13$ & $3.1 \pm 0.8$ \\
\hline
\end{tabular}

\footnotetext{
${ }^{a}$ From Johnson et al. (2001).

${ }^{b}$ Grouping of buffagrasses based on a scale modified from Heng-Moss et al. (2002): HR, highly resistant; MR, moderately resistant; MS, moderately susceptible; HS, highly susceptible.

${ }^{c}$ Chinch bug damage rating from the combined data of the two screening trials based on a $1-5$ visual rating scale with 1 representing no damage and 5 representing damage $\geq 70$ or plant death.

${ }^{d}$ Mean no. of chinch bugs from the combined data of the two screening trials at termination of studies.

${ }^{e}$ Pubescence rating before infestation based on a 1-5 visual rating scale with 1 representing no pubescence and 5 representing dense pubescence as reported by Johnson-Cicalese et al. (1998).

${ }^{f}$ Gulsen et al., data unpublished.
}

\section{Materials and Methods}

Plant Material. Forty-eight buffalograss genotypes were evaluated for chinch bug resistance. These genotypes included 42 accessions from diverse geographic locations, four cultivars, and two other genotypes (Table 1). The genotypes represent all ploidy levels: diploid, triploid, tetraploid, pentaploid, and hexaploid. Vegetative clones of the 42 genotypes were obtained from a collection located at Utah State University, Logan, UT. Primed seeds of 'Cody' and 'Bowie' were planted from commercial sources. Stolons of '378', 'Density', 91-118, and 95-55 were obtained from plantings at the John Seaton Anderson Turfgrass Research Facility located near Mead, NE. The buffalograss genotypes were planted in 15 by 15 -cm pots containing a soil mixture of peat $35 \%$ :vermiculite $32 \%$ : 
soil $9 \%$ :sand $24 \%$. Soil was saturated biweekly with a soluble fertilizer ( $21 \mathrm{~N}-3.5 \mathrm{P}-15 \mathrm{~K})$ containing $200 \mathrm{mg} /$ liter nitrogen and micronutrients. The greenhouse was maintained at $25 \pm 1^{\circ} \mathrm{C}$ with supplemental light supplied by metal halide lamps with a photoperiod of 15:9 (L:D) h.

Chinch Bug Screening. On 15 May 2003, single clones of the 48 genotypes were vegetatively propagated. The clones were propagated using stolons and were grown in 3.8 by $21.0-\mathrm{cm}$ containers. Plants were maintained as described previously. The screening procedure described by Heng-Moss et al. (2002) was used in this study.

All plants were trimmed to the soil surface before chinch bug introduction to ensure a similar growth stage of the plants. On 7 July 2003, chinch bugs ( $B$. occiduus) were collected from infested buffalograss sites with a vacuum (model \#820B, Bioquip, Gardena, CA), sifted through a 2-mm mesh screen, and collected with an aspirator. Chinch bugs were held in the lab for $48 \mathrm{~h}$ to discard injured and dead chinch bugs. Clear acetate tubes $(12 \mathrm{~cm}$ in diameter by $30 \mathrm{~cm}$ in height) were placed over the plants to confine chinch bugs. Eight, fifth instar and adult chinch bugs were introduced into each container. Tube tops were covered with organdy fabric, which were secured with a rubber band. Due to the large number of treatments, all blocks did not contain all treatments. Therefore, treatments were arranged in a modified, incomplete randomized block design with six replications. Turfgrass damage was used to assess plant resistance. After infestation, plants were rated every $3 \mathrm{~d}$ for chinch bug damage, by using a $1-5$ visual rating scale, with 1 , $\leq 10 \% ; 2,11-30 \% ; 3,31-50 \% ; 4,51-70 \%$; and $5, \geq 71 \%$ of leaf area with severe discoloration, or dead tissue (Heng-Moss et al. 2002). The study was terminated when ' 378 ', a susceptible genotype, had an average damage rating of 4 (Heng-Moss et al. 2002). Final damage ratings taken on 8 August 2003 were used in statistical analysis. Plants were placed in Berlese funnels at the termination of the study for chinch bug extraction to determine number per plant (Southwood 1978).

Genotypes were grouped based upon chinch bug damage ratings: $\mathrm{HR}$, highly resistant (damage rating of $\leq 2$ ); MR, moderately resistant (damage rating of $>2$ but $\leq 3$ ); MS, moderately susceptible (damage rating of $>3$, but $\leq 4$ ); and HS, highly susceptible (damage rating of $>4$ ) (modified from Heng-Moss et al. 2002).

A second trial was conducted to further assess the susceptibility of the 48 genotypes to second generation chinch bugs. The second generation chinch bugs were collected from the same field plots, and screening procedures were as described previously. The plants were infested on 9 September 2003, and final damage ratings were taken on 10 November 2003.

Leaf Pubescence. Leaf pubescence ratings were taken on the 48 genotypes by using the procedures described by Johnson-Cicalese et al. (1998). Leaf pubescence ratings were made before chinch bug introduction. A 1-5 rating scale was used, with 1 repre- senting no pubescence and 5 representing dense pubescence.

Statistical Analysis. Mixed model analysis (SAS version 8.0, SAS Institute, Cary, NC) was used to detect treatment differences in chinch bug damage ratings, mean number of chinch bugs, and pubescence ratings among buffalograss genotypes. Means were separated using Fisher's least significant difference (LSD). A Hartley's F $_{\text {Max }}$ test (Hartley 1950) was performed to determine homogeneity of variance between the first and second trials.

\section{Results and Discussion}

$\mathrm{F}_{\text {Max }}$ values of the chinch bug damage rating and mean number of chinch bugs detected in the two separate trials were 1.0 and 1.5 , respectively $(\mathrm{df}=235$, $235)$. Results of the two screening trials were combined, because the $\mathrm{F}_{\mathrm{Max}}$ test indicated no significant differences between the variances for chinch bug damage ratings, and mean number of chinch bugs.

Significant differences were detected for chinch bug damage among the buffalograss genotypes studied $(F=8.6 ; \mathrm{df}=45,523 ; P=0.0001)$ (Table 1$)$. The LSD was 0.7 . Chinch bug damage ratings ranged from 1.5 to 4.5, with the genotype 184 having the lowest rating (1.5) and genotype 119 the highest rating (4.5). The genotypes 184, 91-118, 196, and PX3-5-1 were highly resistant with damage ratings of $<1.7$. The number of moderately resistant genotypes was 22 . Their ratings ranged from 2.2 to 3.0. Nineteen genotypes were moderately susceptible with ratings ranging from 3.2 to 3.9 . The genotypes 4A, 188, and 119 were highly susceptible.

Of the genotypes studied, 91-118, 'Cody', and ' 378 ' were previously evaluated by Heng-Moss et al. (2002). The results of these trials were consistent with their findings in that 91-118 and ' 378 ' were highly resistant and highly susceptible, respectively. However, 'Cody', a seeded-type with considerable genotypic variation, had a slightly different damage rating, hence the difference was likely due to its inherent variation. The plant tissues from a single genotype of 'Cody' may not represent total variation of this cultivar.

There was no significant correlation $(r=0.07)$ between chinch damage rating and ploidy level. The lack of correlation between ploidy level and chinch bug resistance suggests that extra gene copies in higher ploidy levels do not change resistance. Therefore, the use of a lower ploidy level, such as a diploid may assist inheritance studies for chinch bug resistance because of the relative ease of following segregating traits and the requirement of fewer progenies from a mapping population.

The mean number of chinch bugs was significantly different for the genotypes tested $(F=6.0, \mathrm{df}=45$, 523; $P=0.0001 ; \mathrm{LSD}=25$ ) with the mean number being $67 \pm 22$. The genotypes 123,136 , and 34 had the highest chinch bug infestation levels with means of $150 \pm 48,102 \pm 20$, and $100 \pm 31$, respectively. Genotype 123 was moderately susceptible, whereas 136 and 34 were moderately resistant. This response may 
infer tolerance as a category of resistance for these two genotypes. Genotype 184, a highly resistant type, and seven moderately resistant genotypes had a considerably lower number of chinch bugs, $<54$, suggesting antixenosis and/or antibiosis as a category of resistance. There was no correlation between chinch bug number, ploidy level $(r=0.1)$, and pubescence $(r=$ $-0.04)$. There was a significant negative correlation $(r$ $=-0.39)$ between the mean number of chinch bugs and chinch bug damage ratings $(P=0.01)$. The negative correlation between the mean number of chinch bugs and chinch bug damage ratings may be caused by a weakening of susceptible plants in response to chinch bug infestation that may limit insect fecundity.

The 48 genotypes differed in pubescence expression $(F=44 ; \mathrm{df}=45,523 ; P=0.0001)$ (Table 1$)$. Fifteen of 48 genotypes had a very low pubescence rating of $\leq 2.0$. This group included two highly resistant genotypes, 196 and PX3-5-1. Another highly resistant genotype, 91-118, had a moderately low pubescence rating of 2.7. No correlation $(r=0.12)$ was observed between pubescence and chinch bug damage. Johnson-Cicalese et al. (1998) reported a negative correlation between pubescence and resistance to mealybug. Genotypes with high chinch bug resistance and low pubescence could be used in breeding programs interested in multiple insect resistance.

Johnson-Cicalese et al. (1998) found mealybug damage ratings to be positively correlated with buffalograss pubescence levels. Chinch bug damage ratings, however, were not highly correlated to pubescence in this study $(r=0.12)$. Mealybugs and chinch bugs feed by removing nutrients from the leaves, stolons, and other tissues of buffalograss plants. JohnsonCicalese et al. (1998) suggested that mealybugs may prefer buffalograss with pubescence because the hairs may provide a foothold for early instar mealybugs. Chinch bugs, however, are highly mobile insects and will not benefit from pubescence, which seems to be the most likely reason for the low correlation between pubescence and chinch bug damage ratings. Although correlations between ploidy level and pubescence were not significant at the $5 \%$ probability level (data not shown), there was a weak correlation $(r=0.25)$ at the 0.10 probability level, which may be explained by dosage effect of extra copies of the genes controlling pubescence at higher ploidy levels.

Based on chinch bug damage rating, chinch bug resistance is likely a quantitative trait because it is difficult to classify (Table 1; Fig. 1). Quantitative traits are controlled by two or more genes and typically show a greater number of intermediates. This response was observed in this study, where a greater number of moderately resistant and moderately susceptible genotypes compared with highly resistant and highly susceptible were found.

It is notable that no correlation $(r=0.07)$ was found between chinch bug damage and ploidy level. However, unlike diploid and tetraploid buffalograsses, hexaploids have higher adaptation ranges from Mexico to Canada (Johnson et al. 2001). Hexaploids may have diversified the functions of the extra genes, pro-

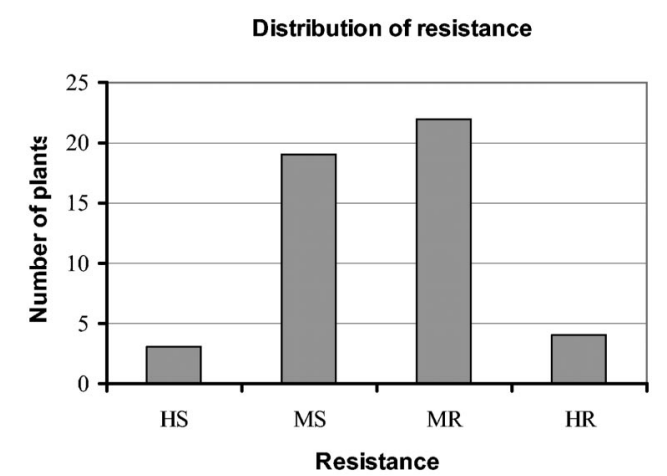

Fig. 1. Distribution of resistance among buffalograss genotypes tested: HR, highly resistant, damage rating from 1.0 to 2.0 ; MR, moderately resistant, damage rating from 2.1 to 3.0; MS, moderately susceptible, damage rating from 3.1 to 4.0; and HS, highly susceptible, damage rating from 4.1 to 5.0.

viding them adaptation to broader climatic zones. Wendel (2000) reported such responses are common in polyploid plant species.

Forty-two genotypes studied represented natural populations collected from a large part of the North American Great Plains (Kenworthy et al. 1999) and are representative of natural populations. Because this population was based on a random sampling procedure, the resistance distribution should reflect those of a natural population. Therefore, additional germplasm with chinch bug resistance likely exists and should be available for future collection.

We evaluated a considerable number of genotypes in a study that were repeated in time. Although high numbers were used, the results of the two trials were consistent. We used a modified partially balanced incomplete block design with increasing specific pairwise comparisons. This design allowed a wide comparison among the genotypes and increased germplasm screening efficiency.

These results indicate the genetic source of resistance to chinch bugs exists in buffalograss germplasm. Highly resistant genotypes can be used in breeding programs to further improve buffalograss cultivars. They are also useful to form synthetic cultivars that broaden the genetic background in a seeded buffalograss turf, which is one of the main strategies to increase turfgrass resistance to herbivorous insects. This research demonstrates additional useful variation to chinch bug feeding among buffalograss genotypes with increasing ploidy levels and suggests the potential to improve buffalograss resistance to B. occiduus.

\section{Acknowledgments}

We gratefully acknowledge T. Eickhoff and W. Anderson for technical assistance and L. Young for experimental design and statistical analysis. Voucher specimens of B. occiduus have been submitted to the University of Nebraska State Museum, Lincoln, NE. This research was supported in part by the University of Nebraska Agricultural Experiment Station Project 17-078, the United States Golf Association, and 
the Nebraska Turfgrass Association. This is paper number 14557 of the journal series of the Agricultural Research Division, University of Nebraska-Lincoln.

\section{References Cited}

Baxendale, F. P., T. M Heng-Moss, and T. P. Riordan.. 1999. Blissus occiduus (Hemiptera: Lygaeidae): a chinch bug pest new to buffalograss turf. J. Econ. Entomol. 92: 11721176.

Beard, J. B. 1973. Turfgrass: science and culture. Prentice Hall, Englewood Cliffs, NJ.

Bird, R. D., and A. V. Mitchener. 1950. Insects of the Season 1949 in Manitoba. Can. Insect Pest Rev. 28: 41.

Eickhoff, T. E., F. P. Baxendale, T. M. Heng-Moss, and E. E. Blankenship. 2004. Turfgrass, crop, and weed host of Blissus occiduus (Hemiptera: Lygeidae). J. Econ. Entomol. 97: 67-73.

Farstad, C. W., and Staff. 1951. Insects of the Season in Alberta, 1950. Can. Insect Pest Rev. 29: 18

Ferris, G. F. 1920. Insects of economic importance in the cape region of lower California, Mexico. J. Econ. Entomol. 13: 463-467.

Hartley, H. O. 1950. The maximum F-ratio as a shortcut test for heterogeneity of variance. Biometrika 37: 308-312.

Heng-Moss, T. M., F. P. Baxendale, T. P. Riordan, and J. E. Foster. 2002. Evaluation of buffalograss germplasm for resistance to Blissus occiduus (Hemiptera: Lygaeidae). J. Econ. Entomol. 95: 1054.

Heng-Moss, T. M., F. P. Baxendale, T. P. Riordan, L. Young, and K. Lee. 2003. Chinch bug-resistance buffalograsses: an investigation of tolerance, antixenosis, and antibiosis. J. Econ. Entomol. 96: 1942-1951.

Johnson-Cicalese, J. M., F. P. Baxendale, T. P. Riordan, and T. M. Heng-Moss. 1998. Identification of mealybug (Homoptera: Pseudococcidae) resistant turf-type buffalograss germplasm. J. Econ. Entomol. 91: 340-346.

Johnson, P. G., K. E. Kenworthy, D. L. Auld, and T. P. Riordan. 2001. Distribution of buffalograss polyploid variation in the southern Great Plains. Crop Sci. 41: 909-913.

Kenworthy, K. E., D. L. Auld, D. B. Wester, R. E. Durham, and C. B. McKenney. 1999. Evaluation of buffalograss germplasm for induction of fall dormancy and spring green-up. J. Turfgrass Manage. 3: 23-42.

Parker, J. R. 1920. The chinch bug in Montana. J. Econ. Entomol. 13: 318-322.

Reinert, J. A., P. R. Heller, and R. L. Crocker. 1995. Chinch bugs, pp. 38-42. In R.L. Brandenburg and M.G. Villani [eds.], Handbook of turfgrass insect pests. Entomological Society of America, Lanham, MD.

Riordan, T. 1991. Buffalograss. Grounds Maint. 26: 12-14.

Slater, J. A. 1964. A catalog of the Lyagaeidae of the world. University of Connecticut, Storrs, CT.

Southwood, T.R.E. 1978. Ecological methods. Halsted, New York.

Tashiro, H. 1987. Turfgrass insects of the United States and Canada. Cornell University Press, Ithaca, NY.

Wendel, J. F. 2000. Genome evolution in polyploids. Plant Mol. Biol. 42: 225-249.

Wenger, L. E. 1943. Buffalograss. Kans. Agric. Expt. Stn. Bull. 321: 1-78.

Received 13 April 2004; accepted 9 August 2004 